\title{
From World War to Class War: The Rebound of the Rich
}

\section{De guerre mondiale à guerre des classes : la remontée des riches}

\author{
by ROBERT G. EVANS \\ Professor of Economics \\ University of British Columbia \\ Vancouver, BC
}

\begin{abstract}
Incomes in Canada, as in many other countries, are becoming increasingly unequal. In North America this process has several notable features. First, after 40 years of stability, income has since 1980 been increasingly concentrated in the hands of the top $0.01 \%$ of earners. Second, this concentration correlates with an explosion in the relative earnings of corporate CEOs, a sort of "corporate kleptocracy." Third, the top earners have appropriated most of the productivity gains over this period. The resources and political influence of the super-rich underlie the growing prominence of the "elite" agenda: lower taxes, smaller government and privatization or shrinkage of social programs. The marketing of this agenda may explain much of the nonsense that contaminates health policy debates.
\end{abstract}




\title{
Résumé
}

Au Canada, comme dans de nombreux autres pays, on observe de plus en plus de disparités dans les revenus. En Amérique du Nord, ce processus comporte plusieurs caractéristiques importantes. En premier lieu, après 40 ans de stabilité, les revenus sont de plus en plus concentrés entre les mains de 0,01\% de la population active depuis 1980 . En deuxième lieu, cette concentration correspond à une explosion des revenus relatifs des PDG des grandes sociétés - une sorte de «kleptocratie des entreprises ». En troisième lieu, les personnes ayant les meilleurs revenus d'emploi se sont accaparé la plupart des gains de productivité pendant cette période. Les ressources et l'influence politique des super-riches sont à la source de la dominance croissante des intérêts de l'« élite », à savoir, des taxes réduites, un gouvernement plus petit et la privatisation ou la réduction des programmes sociaux. La promotion de ces intérêts peut expliquer une bonne partie des balivernes qui contaminent les débats sur les politiques relatives à la santé.

Above all things, good policy is to be used, that the treasure and moneys, in a state, be not gathered into few hands... money is like muck, not good except it be spread.

- Sir Francis Bacon, Essay XV

\begin{abstract}
The distribution of income in Canada, as in many other countries, is becoming increasingly unequal. This is not exactly late-breaking news, though the issue seems to have stayed largely below the public radar. Several recent papers, however, have focused in particular on the highest incomes and placed this trend in historical context.
\end{abstract}

\section{Forward to the Past}

Income in North America is now concentrated in the hands of the very, very wealthy to a degree not seen since before the Second World War. And with greater wealth comes greater political influence; public policy, including health policy, is increasingly driven by the priorities of the wealthy, overriding the concerns of the general population.

Piketty and Saez (2006) examine the concentration of income in the United States over most of the last century, with comparative data for Canada and several other countries. Their graph 1A (Figure 1), drawn from income tax data, tells a remarkable story.

Between 1919 and 1940, the top 10\% of American earners accounted for a relatively steady $43 \%-46 \%$ of total incomes. The onset of war, however, brought major increases in corporate taxes and steeply progressive individual taxation. Top earners' 
FIGURE 1. Top decile income shares in the United States, 1917-2002

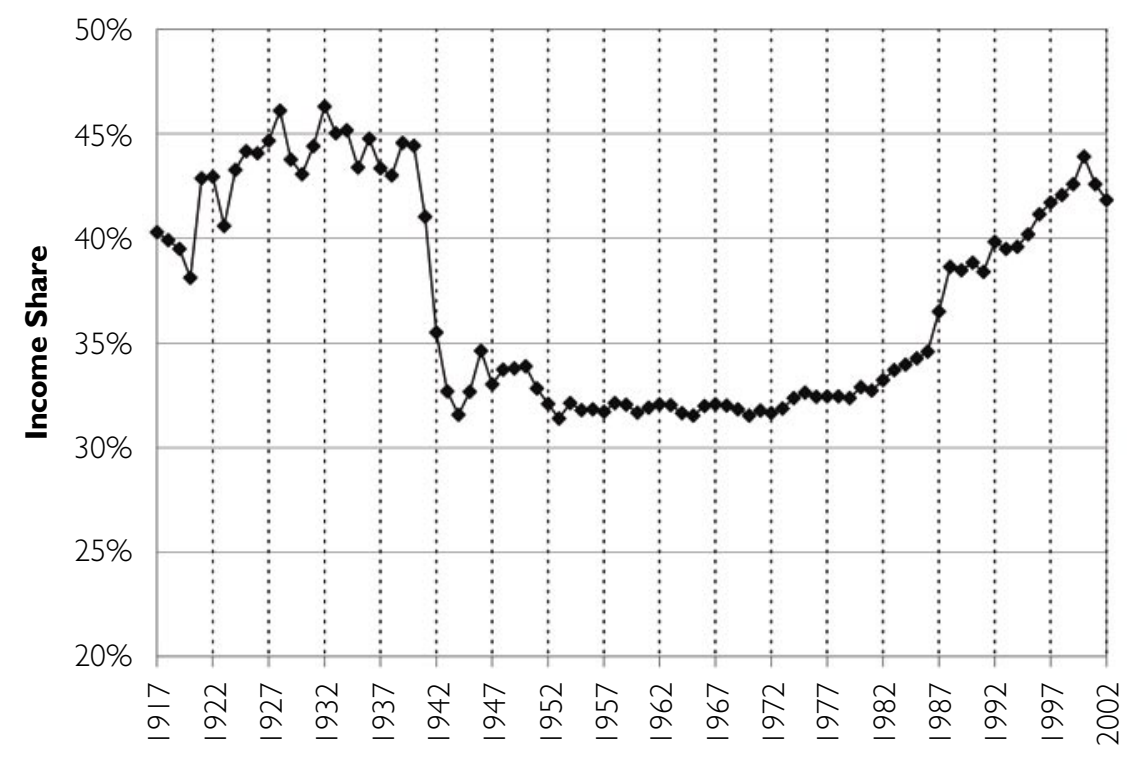

share plummeted to about one-third, and stayed there for the next 40 years. In that era, studying income distribution was likened to watching paint dry, or grass grow.

Then came the 1980s, and coincidentally, the elections of Ronald Reagan and Margaret Thatcher. ("You think the income distribution can't be changed? Watch me!") Money began to flow back to the long end. Today, the pre-war relationship has largely been re-established.

\section{The Higher, the Better}

Times are very good in the top decile, but the more thinly one "top-slices" the income distribution, the better they get. The top $1 \%$ saw their share increase from $8 \%$ to $17 \%$. But the gains still farther up are even more extraordinary. The highest-earning tenthousandth, representing perhaps about 30,000 people, increased their share from $0.5 \%$ to nearly $3 \%$ of all incomes earned in the United States. Two and a half percentage points may not seem like much, but it was enough to raise these people's relative incomes by a factor of six, from about 50 times the national average to about 300 times.

As Figure 2 shows, Canada and the United Kingdom have followed the U.S. pattern (Ibid., Figure 3A). Their trends are, as usual, less extreme than in the United States, but over 20 years the top one-thousandth of Canadian earners have more than 
FIGURE 2. Top $0.1 \%$ income shares in English-speaking countries

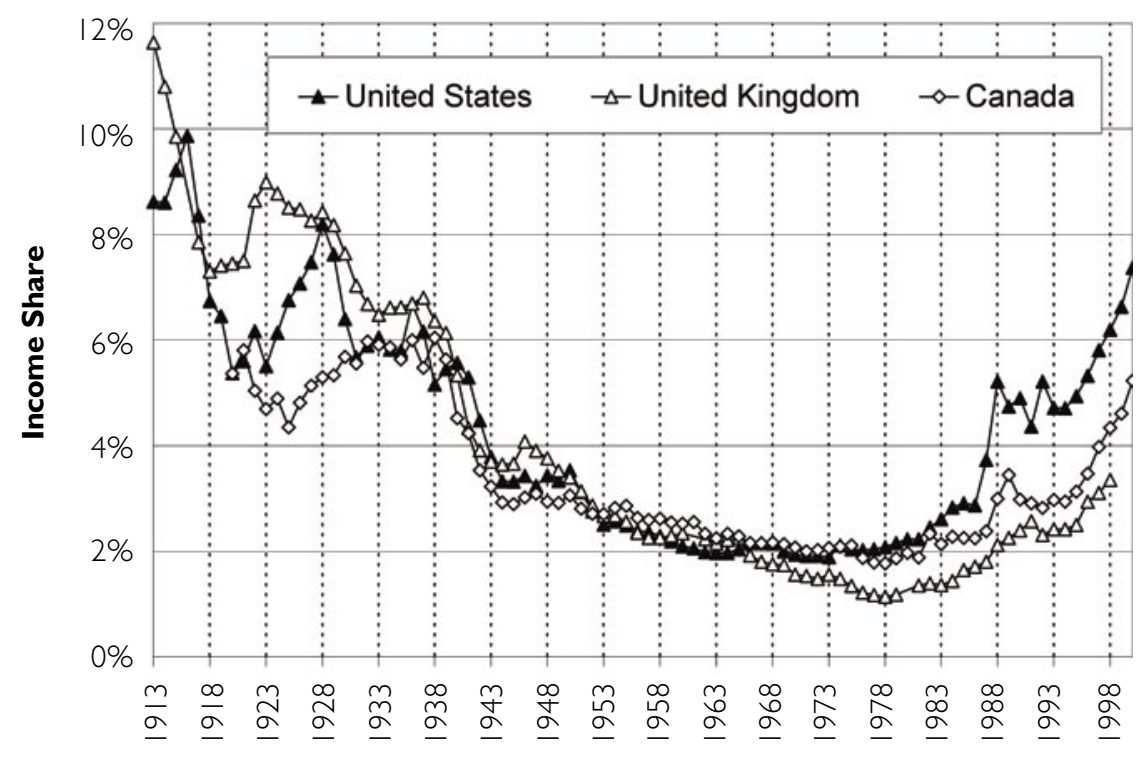

doubled their share, and the top $0.01 \%$ - representing about 3,300 people - saw their share rise from $0.5 \%$ to $1.8 \%$ (Saez and Veall 2004). Yet in France and Japan (Figure 3)(Piketty and Saez, Figure 3B), the pattern is totally different and seems to refute any explanation based on universal economic laws at work in the development of advanced industrial economies. One might want to focus instead on country-specific institutions and policies.

\section{Dr. Pangloss, Right on Cue}

Nevertheless, a common response by economists to increasing economic inequality has been to look for general external factors unrelated to particular institutions or policies. The favourite code phrase is "skill-biased technological progress."

Continuing technological innovation makes possible ever-increasing productivity and correspondingly ever-increasing incomes - the Holy Grail of Growth. But it just happens - it's no one's choice or fault, just part of the structure of the universe - that at present, technical progress is increasing the demand for, and thus the relative incomes of, the highly educated and highly skilled. Incomes are more unequal because, given present technology, individual productivity is more unequal. (What could be fairer than that?) 
FIGURE 3. Top 0.1\% income shares in France and Japan

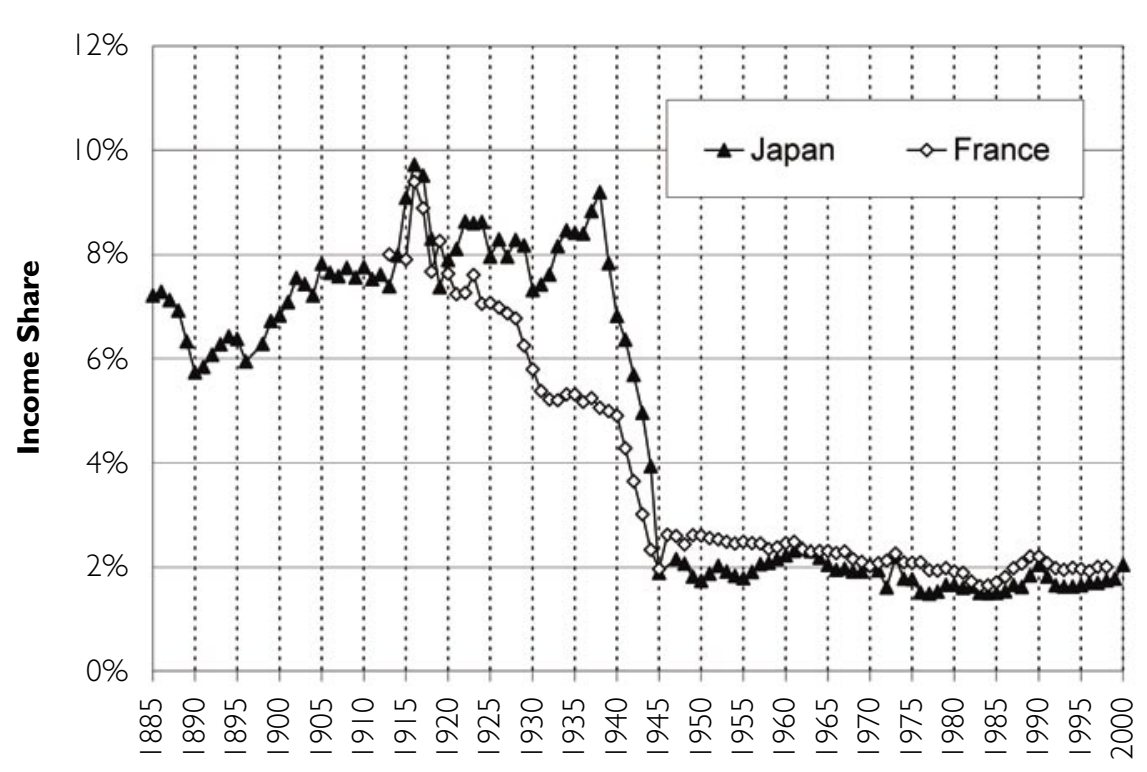

So economic growth, which is very good and very important, comes with the side effect of increasing economic inequality, which some people may think is not so good. But it would be very wrong-headed for governments to interfere with the allocation of incomes by the impersonal forces of the market. Imposing more progressive taxation, for example, or expanding income support programs or the provision of public services, or even raising minimum wages or facilitating unionization, would risk lowering the rate of economic growth and would thus be really bad. Such policies would condemn a society to progressively declining (relative) incomes, compared with more economically enlightened countries.

Policy should rather seek to minimize public interventions, regardless of the distributional consequences, in order to encourage even more rapid growth. If increasing inequality is a concern, the proper response is for those losing ground to get more training. Send the children to the Harvard Business School - or even enroll yourself.

\section{The Corporate Kleptocrats}

Not such a bad idea, at that. (But don't expect any public support - see below.) Paralleling the march of inequality across North America has been an extraordi- 
nary increase in the compensation of corporate senior executives, and particularly of CEOs. Frydman (2005) presents the results of a long-term study of a sample of major American corporations, many with substantial Canadian operations. Her focus is on testing various economic explanations for this recent increase, but the basic data are interesting enough.

Over the decade of the 1970s, the median total annual compensation (averaged over the three top executives of each of the corporations studied) was $\$ 1.03$ million (USD of 2000). This was a slow and unremarkable rise from $\$ 890,000$ in the period 1936-1939. But then median executive earnings took off: $\$ 1.53$ million in the 1980s, $\$ 2.90$ million in

\section{The ratio of $\mathrm{CEO}$ compensation to average production workers' pay, which had averaged 42 to one in 1982 , was 10 times higher -431 to one - in $2004 \ldots$} the 1990 s and $\$ 5.23$ million in 2000-2003. The spread within the corporate ranks also widened dramatically; average total compensation among the 90 th percentile of corporate executives rose from $\$ 2.06$ million in the

1970 s to $\$ 22.19$ million in $2000-2003$. Top earnings rose more than $9 \%$ per year, compounded over 27 years!

The rest of the American labour force fared somewhat less well. The ratio of CEO compensation to average production workers pay, which had averaged 42 to one in 1982, was 10 times higher - 431 to one - in 2004 (Anderson et al. 2005).

These are staggering increases. They correspond to an intriguing observation by Piketty and Saez (2006). The pre-war period was still the era of the rentier; the superrich were sustained primarily by income from investments. But the dramatic resurgence after 1980 was powered by increases in salaries and business earnings - including those of corporate executives. It appears that in the current era, those at the top have found alternative ways of extracting and concentrating wealth from the corporate sector.

But this would imply conscious agency, inconsistent with conventional economic thinking. A more economistical approach interprets CEO earnings as just another manifestation of "skill-bias," in this case skill-biased environmental change. The corporate world has become dramatically more complex and competitive, what with globalization and the Internet and all that, such that the value to a corporation's shareholders of the very best top management - the super-stars - has greatly increased. (But are they all super-stars now?)

The argument rests on faith in the collective intelligence and ability of corporate directors in matching rewards with contributions. Empirical support for this is distinct- 
ly dubious; the CEO who took Moore Corporation shares from $\$ 16$ to $\$ 3$, for example, picked up US\$40 million on his way out the door. And then there is John Roth ...

Economic faith insists, nonetheless, that on average, CEOs must be worth the money, or rational, fully informed boards of directors, wholly dedicated to the enhancement of shareholder value (the PC term for profit), would not offer such whacking great compensation packages. The existence of these idealized boards has been vigorously challenged by Bebchuk and Fried $(2004,2005)$."We show that, under current legal arrangements, boards cannot be expected to contract at arm's length with the executives whose pay they set" (Bebchuk and Fried 2005).

Faith or no, however, there is in fact no logical link from the argument that exceptional managerial talent confers a corresponding competitive advantage on the corporation, and the conclusion that a general growth in executive compensation will raise the overall productivity of a society. (Conversely, capping hockey players' salaries will not lower the average quality of play in the NHL.) Nor, more generally, does economic theory provide any a priori basis for the proposition that greater inequality is associated with greater economic efficiency. The "equity-efficiency tradeoff" popularized by Arthur Okun (1975) was simply a theoretical blunder, taken up enthusiastically in "pop" economics presumably because of its political attractiveness.

The relationship between inequality and growth is thus an empirical one, and as usual the empirical studies are mixed. It depends upon when, and where, and what else is going on. For what it's worth, we do find that the rate of growth of real national income per head in the English-speaking countries is substantially higher than in France or Japan, at least over the 10- and five-year periods prior to 2003. But it isn't worth very much.

\section{Where Did All the Productivity Go?}

The apparently central issue of inequality and growth turns out to be irrelevant, a red herring. For most of us in North America there hasn't been much growth. The gains have all been captured at the top end.

Between 1976 and 1990, average personal income per capita in Canada (inflationadjusted) rose only $0.6 \%$ per year. From 1990 to 2000 it didn't grow at all (Saez and Veall 2004, 2005). A similar pattern emerges in the United States: "We show that over the entire period 1966-2001, as well as over 1997-2001, ... median real wage and salary income barely grew at all ... because half of the income gains went to the top 10 percent of the income distribution..." (Dew-Becker and Gordon 2005).

The corporate kleptocrats are making out like bandits, but none of this wealth is trickling down. So even if public policies to mitigate inequality were to threaten the aggregate rate of growth, what have most of us got to lose?

These are heretical thoughts, totally out of synch with the economic zeitgeist. 
The public agenda has for a number of years been prodded in the opposite direction - "smaller government," tax cuts, privatization (perhaps starting with P3s), de-regulation, and ever-greater scope for free markets. But who or what is calling forth these geists? Surveys suggest that at least in Canada these are not the priorities of the general public, only of the "elites" - and no wonder.

\section{The corporate kleptocrats are making out like bandits, but none of this wealth is trickling down. So even if public policies to mitigate inequality were to threaten the aggregate rate of growth, what have most of us got to lose?}

The contrast of priorities was nicely illustrated by Conrad Black's vitriolic editorial after the federal election of 2000. Canadian governments are engaged in "a process of taking money from people who have earned it and redistributing it to people who haven't, more or less in exchange for their votes" (Black 2000). Lord Black's concept of "earned" may be somewhat

idiosyncratic; he is currently under indictment in the United States for fraud and racketeering. But if we strike that word, he is quite correct. Governments, in every country, are primarily and pretty much the only institutions for redistributing income and inkind benefits down the income spectrum. If voters support that, well, isn't that how democracies are supposed to work?

\section{Starving the Welfare State}

The counter-strategy for the wealthy is simple enough. Cripple the fiscal capacity of governments through tax cuts, particularly for themselves. After all, if you are stinking rich you don't need much of a government. The Welfare State wastes money on all sorts of public services you either do not need, or are perfectly capable of buying privately. And to add insult, governments often interfere with your enterprises in the name of some exiguous "public interest." A Watchman State is quite sufficient.

This agenda is well advanced in the United States. The tax cuts under the Bush administration have created a federal debt that will hobble government for years or decades. And the beneficiaries have indeed been the wealthy. The New York Times (Johnston 2006) reports that in 2003, cuts to taxes on investment income transferred an average of $\$ 500,000$ each to those with incomes over $\$ 10$ million, bringing their average gains from combined Bush tax cuts to just over $\$ 1$ million. Of the total revenue forgone, $42 \%$ went to those with incomes over $\$ 1$ million $-0.1 \%$ of all taxpayers. 
Canada is very different, so far. The federal government has been running surpluses for years and is (very slowly) reducing the federal debt. But the same pressures are at work. The Alberta "flat tax" and Senator Kirby's proposed income-linked healthcare premiums both significantly lower the tax burdens of the highest earners, as did the B.C. tax cuts of 2001. The subsequent program cuts required to restore budget balance have been mostly "wealthy-friendly." Meanwhile, since the mid-1990s the federal and provincial governments have between them forgone through tax cuts a sum now "not unadjacent to" $\$ 60$ billion a year. Cumulated over the last decade, these amounts could have made a very big hole in the public debt.

The recent proposals from the Canadian Council of Chief Executives (CCCE) are the most transparent attack on the public sector. Downloading a much greater share of taxation and of responsibility for public programs from the federal to the provincial level is designed to trigger a classic "race to the bottom." Provincial governments would be under increased pressure to compete more aggressively in cutting taxes and public spending. The casualties would certainly include the Canada Health Act and medicare, and probably much of the public support for post-secondary education, but then that's really rather the point, isn't it? The principal beneficiaries? - see above under "Corporate Kleptocrats."

Advocates of this program, including the CCCE, emphasize the importance of international competitiveness and faster economic growth. The New York Times report (Johnston 2006) quotes a lobbyist to the effect that investment earnings should not be taxed at all, because they will be saved and invested, creating more jobs and faster growth. (On this logic, government should perhaps introduce a negative tax for investment earnings.) The new capital investments, and the income they generate, would of course all be owned by the same thin top slice of the income distribution who received the tax breaks in the first place.

As every economist knows, however, government surpluses are an alternative and equally effective form of national savings. They flow directly into the bond market as government debt is repaid, and are there available to private investors. But the ownership of this form of savings and investment is not concentrated among the very wealthy, so no one lobbies for bigger surpluses. Indeed, the public commentary in Canada seems quite negative - better, apparently, to promote growth through corporate tax cuts for the wealthy. Curious.

\section{Money, Myths and Medicine}

But what has all this got to do with healthcare policy? The connection, I suggest, is that the attack on the Welfare State, and the erosion of the post-war consensus on the role of government, parallels the dramatic increase in the concentration of wealth. And public systems of healthcare are a centrepiece of the Welfare State. They are a natural 
focus for attack on the Willie Sutton Principle - "that's where the money is" - and smaller government requires a larger role for private finance. Public healthcare also offers, at least outside the United States, less scope for the corporate kleptocracy. But it is also by far the most widely used and strongly supported of any public service. To discredit government, you must discredit public healthcare.

And you must discredit government - as the Dark Lord clearly recognized - if you are to reduce its depredations on the wealth of the upper classes. When he bought the Southam chain and founded the National Post, Black was quite open about

They have their roots in the simple fact that public healthcare systems transfer both resources and access down the income spectrum, from the healthy and wealthy to the unhealthy and unwealthy. his intent to use them as a propaganda vehicle, to shift the centre of gravity of public debate in Canada. Whatever his personal fate, he appears to have succeeded. The torch has now been picked up by the Aspers and CanWest Global. (The Globe and Mail and La

Presse, controlled respectively by the billionaire Thomson and Desmarais families, emphasize their strong commitment to press independence.)

Meanwhile, a string of soi-disant "think tanks" has emerged on the model of the highly successful Fraser Institute, privately and well financed, to serve as propaganda outlets for the corporate sector and to undermine confidence in governments. (As always, the original models are American.) It works; behind the notorious Chaoulli decision, for example, lie at least 15 years of anti-medicare disinformation, seeping into the ill-informed and inadequately critical minds of the majority court. ${ }^{1}$

Erroneous and often patently absurd claims about healthcare and the "public-private mix" have been around in more or less the same form for many decades. They have their roots in the simple fact that public healthcare systems transfer both resources and access down the income spectrum, from the healthy and wealthy to the unhealthy and unwealthy. Public financing can also limit the transfer of wealth from those who pay for care to those who are paid for it. These effects are ever-fertile sources of well-worn and specious arguments as to why such transfers/limitations are unfair, inefficient and unhealthy.

But why have these myths been promulgated with increasing energy over the last quarter century, becoming embedded, like coproliths, in the media and in political debate? They are no less specious, but the political landscape has changed dramatically. Medicare is now very much on the defensive. The spectacular growth in the incomes 
of the super-rich, expanding the resources behind their agenda, may offer at least part of the explanation. If we are back to a pre-war income distribution, how much of our post-war social policies can survive?

\section{NOTES}

1.... one of the most unsettling aspects of the Chaoulli decision was the misuse, and ignorance, of evidence" (Barer 2005: 217).

\section{REFERENCES}

Anderson, S., J. Cavanagh, S. Klinger and L. Stanton. 2005 (August 30). Executive Excess 2005: Defense Contractors Get More Bucks for the Bang. 12th Annual CEO Compensation Survey. Washington/Boston: Institute for Policy Studies/United for a Fair Economy.

Barer, M.L. 2005. "Experts and Evidence: New Challenges in Knowledge Translation." In C.M. Flood, K. Roach and L. Sossin, eds., Access to Care, Access to Justice (pp. 216-19). Toronto: University of Toronto Press.

Bebchuk, L. and J. Fried. 2004. Pay without Performance: The Unfulfilled Promise of Executive Compensation. Cambridge, MA: Harvard University Press.

Bebchuk, L. and J. Fried. 2005. Pay without Performance: Overview of the Issues. Cambridge, MA: Harvard Law and Economics Discussion Paper \#528.

Black, C. 2000 (December 1). "The Most Boring Election in History”. National Post: A18.

Dew-Becker, I. and R.A. Gordon. 2005 (December)."Where Did the Productivity Growth Go? Inflation Dynamics and the Distribution of Income." NBER Working Paper \#11842. Cambridge, MA: National Bureau of Economic Research.

Frydman, C. 2005 (November 18)."Rising through the Ranks: The Evolution of the Market for Corporate Executives, 1936-2003." Unpublished manuscript. Cambridge, MA: Harvard University.

Johnston, D.C. 2006 (April 5). "Big Gain for Rich Seen in Tax Cuts for Investments." New York Times. Retrieved July 13, 2006. <http://www.nytimes.com/2006/04/05/business/05tax.html?ex $=1301889600 \& \mathrm{en}=2 \mathrm{f0a} 40120544 \mathrm{a} 89 \mathrm{c} \& \mathrm{ei}=5088 \&$ partner $=$ rssnyt $\& \mathrm{emc}=\mathrm{rss}>$.

Okun, A.M. 1975. Equity and Efficiency: The Big Tradeoff. Washington, DC: Brookings Institution.

Piketty, T. and E. Saez. 2006 (January)."The Evolution of Top Incomes: A Historical and International Perspective." NBER Working Paper \#11955. Cambridge, MA: National Bureau of Economic Research.

Saez, E. and M.R. Veall. 2004."The Evolution of High Incomes in Canada, 1920-2000." Unpublished manuscript (a longer version of Saez and Veall 2005, q.v.).

Saez, E. and M.R. Veall. 2005."The Evolution of High Incomes in Northern America: Lessons from Canadian Evidence." American Economic Review 95(3): 831-49. 